\title{
Correction to: Patient Engagement Partnerships in Clinical Trials: Development of Patient Partner and Investigator Decision Aids
}

\author{
Monica Parry ${ }^{1}$ (1) Ann Kristin Bjørnnes ${ }^{2} \cdot$ Karine Toupin-April $^{3,4} \cdot$ Adhiyat Najam $^{5} \cdot$ David Wells $^{5} \cdot$ Aditi Sivakumar $^{4}$. \\ Dawn P. Richards ${ }^{6} \cdot$ Tina Ceroni $^{7} \cdot$ Marianne Park $^{8} \cdot$ Anne K. Ellis $^{9} \cdot$ Ian Gilron $^{10} \cdot$ Susan Marlin $^{6}$
}

Published online: 18 November 2020

(c) The Author(s) 2020

\section{Correction to: \\ The Patient - Patient-Centered Outcomes Research (2020) 13:745-756 \\ https://doi.org/10.1007/s40271-020-00460-5}

In the original version of the article, unfortunately Susan Marlin's affiliation has been published incorrectly.

Previously read as

Patient Partner with Diabetes Action Canada, Toronto, ON, Canada.

It should read:

Clinical Trials Ontario, Toronto, ON, Canada
Open Access This article is licensed under a Creative Commons Attribution-NonCommercial 4.0 International License, which permits any non-commercial use, sharing, adaptation, distribution and reproduction in any medium or format, as long as you give appropriate credit to the original author(s) and the source, provide a link to the Creative Commons licence, and indicate if changes were made. The images or other third party material in this article are included in the article's Creative Commons licence, unless indicated otherwise in a credit line to the material. If material is not included in the article's Creative Commons licence and your intended use is not permitted by statutory regulation or exceeds the permitted use, you will need to obtain permission directly from the copyright holder. To view a copy of this licence, visit http://creativecommons.org/licenses/by-nc/4.0/.

The original article can be found online at https://doi.org/10.1007/ s40271-020-00460-5.

Monica Parry

monica.parry@utoronto.ca

1 Lawrence S. Bloomberg Faculty of Nursing, University of Toronto, 155 College Street, Suite 130, Toronto, ON M5T 1P8, Canada

2 Department of Nursing and Health Promotion, Oslo Metropolitan University, Oslo, Norway

3 School of Rehabilitation Sciences, Faculty of Health Sciences, University of Ottawa, Ottawa, ON, Canada

4 Faculty of Medicine, University of Ottawa, Ottawa, ON, Canada
Patient Partner, Diabetes Action Canada, Toronto, ON, Canada

6 Clinical Trials Ontario, Toronto, ON, Canada

7 Patient Partner, Clinical Trials Ontario, Toronto, ON, Canada

8 Patient Partner, Network of Women with Disabilities, Woodstock, ON, Canada

9 Department of Medicine, Queen's University, Kingston, ON, Canada

10 Departments of Anesthesiology and Perioperative Medicine, Biomedical and Molecular Sciences and School of Policy Studies, Queen's University, Kingston, ON, Canada 